Article

\title{
Polysaccharide-Based Edible Coatings Containing Cellulase for Improved Preservation of Meat Quality during Storage
}

\author{
Anna Zimoch-Korzycka * and Andrzej Jarmoluk \\ Department of Animal Products Technology and Quality Management, Wrocław University of Environmental \\ and Life Sciences, 37 Chelmonskiego St., 51-630 Wrocław, Poland; anna.zimoch-korzycka@upwr.edu.pl \\ * Correspondence: anna.zimoch-korzycka@upwr.edu.pl; Tel.: +48-71-3207-772
}

Academic Editor: Krasimir Vasilev

Received: 19 January 2017; Accepted: 28 February 2017; Published: 2 March 2017

\begin{abstract}
The objectives of this study were to optimize the composition of edible food coatings and to extend the shelf-life of pork meat. Initially, nine meat samples were coated with solutions containing chitosan and hydroxypropyl methylcellulose at various cellulase concentrations: $0 \%, 0.05 \%$, and $0.1 \%$, stored for 0,7 , and 14 days. Uncoated meat served as the controls. The samples were tested for $\mathrm{pH}$, water activity $\left(\mathrm{a}_{\mathrm{w}}\right)$, total number of microorganisms (TNM), psychrotrophs $(\mathrm{P})$, number of yeast and molds (NYM), colour, and thiobarbituric acid-reactive substances (TBARS). The $\mathrm{pH}$ and $\mathrm{a}_{\mathrm{w}}$ values varied from 5.42 to 5.54 and 0.919 to 0.926 , respectively. The reductions in the TNM, P, and NYM after 14 days of storage were approximately $2.71 \log$ cycles, $1.46 \log$ cycles, and $0.78 \log$ cycles, respectively. The enzyme addition improved the stability of the red colour. Significant reduction in TBARS was noted with the inclusion of cellulase in the coating material. Overall, this study provides a promising alternative method for the preservation of pork meat in industry.
\end{abstract}

Keywords: chitosan; hydroxypropyl methylcellulose; cellulase; meat quality; microbiology

\section{Introduction}

Raw meat is highly perishable because it is a good source of nutrients for microorganisms. Microbial growth is the major factor that causes meat spoilage. Unfavourable changes may also occur due to chemical reactions such as lipid and myoglobin oxidation, leading to odour changes and brown colouration of meat, respectively. Biochemical reactions also may lead to moisture loss during storage. These changes are reflected in the texture or flavour of the meat [1].

Edible coatings may improve the quality and extend the shelf-life of fresh meat and meat products. Three types of coatings have been used for this purpose. These coatings are the lipid, protein, and polysaccharide coatings. Two of the most abundant polysaccharides in nature, cellulose and chitosan, are used in the production of films and coatings. Cellulose is composed of glucose with $\beta-1,4$ glycosidic linkages that are very chemically stable, but the native form is insoluble in water. Ethers of cellulose are soluble and are produced by the partial substitution of the hydroxyl groups at positions 2, 3, and 6 of the glucosyl units. The hydroxypropyl methylcellulose (HPMC) is water-soluble and shows good film-forming ability [1]. Chitosan $(\mathrm{CH})$, a deacetylated chitin consisting of $\beta$-(1,4)-2-amino-D-glucopyranose and of $\beta$-(1,4)-2-acetamido-D-glucopyranose [2], with or without other additives, has been shown to have profitable applications in meat preservation [3-5]. Cellulase is a cellulose-degrading lytic enzyme. The presence of similar bonds in the chains of HPMC and $\mathrm{CH}$ ensures their enzymatic digestion by cellulase [6]. Chitooligomers produced during chemical or enzymatic hydrolysis of chitosan display more potent bactericidal effects than chitosan [5,7]. When compared to its effect on Gram-positive bacteria, the lower molecular weight chitosans exert a more 
potent bactericidal effect on Gram-negative bacteria [8]. The antimicrobial activity of the chitooligomers is related to the adsorption of the polymers onto the bacterial cell surface, increasing the permeability of the cell membrane and causing cell death through the loss of essential cellular materials [9].

To the best of our knowledge, the usage of a hydrolytic enzyme (except lysozyme) as an additive in polysaccharide meat coatings for improving its antimicrobial activity is novel. Our FT-IR analysis confirmed the hydrolysis of chitosan by cellulase and showed that the physicochemical properties of such films were comparable to that reported by a previous study [10]. The objective of this study was to optimize the composition of edible food coatings based on hydroxypropyl methylcellulose, chitosan, and cellulase, and to improve the shelf-life and quality of pork meat. Meat quality was assessed from the total number of microorganisms (TNM), number of psychrotrophs (P), number of yeast and mold (NYM), as well as by measuring the colour and thiobarbituric acid reactive substances (TBARS).

\section{Results and Discussion}

\subsection{Microbiology}

The effects of cellulase addition and storage time on the TNM, P, and NYM values are presented in Figures 1-3, respectively. The results showed the simultaneous influence of cellulase and storage time on TNM, P, and NYM. The TNM, P, and NYM were $3.48 \log \mathrm{CFU} / \mathrm{cm}^{2}, 4.65 \log \mathrm{CFU} / \mathrm{cm}^{2}$, and $3.40 \log \mathrm{CFU} / \mathrm{cm}^{2}$, respectively, at time 0 of storage. After 7 days of storage, these values increased to $5.00 \log \mathrm{CFU} / \mathrm{cm}^{2}, 5.84 \log \mathrm{CFU} / \mathrm{cm}^{2}$, and $4.88 \log \mathrm{CFU} / \mathrm{cm}^{2}$ for TNM, P, and NYM, respectively. The final TNM, P, and NYM values were $7.78 \log \mathrm{CFU} / \mathrm{cm}^{2}, 6.84 \log \mathrm{CFU} / \mathrm{cm}^{2}$, and $5.34 \log \mathrm{CFU} / \mathrm{cm}^{2}$, respectively. Malinowska-Pańczyk and Kołodziejska have reported total bacterial counts of $4.3 \log \mathrm{CFU} / \mathrm{g}, 5.8 \mathrm{log} \mathrm{CFU} / \mathrm{g}$, and $7.4 \mathrm{log} \mathrm{CFU} / \mathrm{g}$, and psychrotroph counts of $4.0 \mathrm{log} \mathrm{CFU} / \mathrm{g}$, $5.3 \log \mathrm{CFU} / \mathrm{g}$, and $8.2 \mathrm{log} \mathrm{CFU} / \mathrm{g}$ in minced pork after 0,2 , and 6 days of refrigerated storage, respectively [11]. Although these authors applied $60 \mathrm{MPa}$ pressure at $-5^{\circ} \mathrm{C}$ to extend the shelf-life, the change in the bacterial count after 2 and 6 days of storage was insignificant compared to the untreated sample. The application of $193 \mathrm{MPa}$ pressure $\left(\right.$ at $-20^{\circ} \mathrm{C}$ ) caused a drop in the total bacterial count to $4.1 \mathrm{log} \mathrm{CFU} / \mathrm{g}$ and $5.9 \mathrm{log} \mathrm{CFU} / \mathrm{g}$ and in the psychrotroph count to $2.6 \mathrm{log} \mathrm{CFU} / \mathrm{g}$ and $4.9 \log \mathrm{CFU} / \mathrm{g}$ after 2 and 6 days, respectively. Bacterial growth in pieces of meat can be more readily controlled compared with that in minced meat. At time 0 of storage, the cellulase dose had no effect on the amounts of the tested groups of microorganisms in the samples. However, compared with the controls, the TNM dropped by $0.85 \log$ cycles and $2.71 \log$ cycles at $0.1 \%$ cellulase concentration after 7 and 14 days of storage, respectively. Zhao et al. analysed the microbial growth in vacuum-packed pork during its cold storage and noted a similar reduction (2.27 CFU/g) after 14 days [12]. The inhibitory effect is related to the presence of chitosan in the coating material. Chitosan inhibits the growth of bacteria, fungi, and yeast [13]. It exerts a particularly potent inhibitory effect against bacteria [14]. Cellulase has been shown to hydrolyse chitosan resulting in the production of chitooligomers [10]. Available evidence suggests that chitooligomers may have better antimicrobial properties than chitosan [15].

The psychrotrophic bacteria in the meat were sensitive to the simultaneous effects of cellulase addition in separated periods of time, and the value of $p$ was $0.59 \log$ cycles lower in the C0.1T7 sample than that determined for the Control T7 sample. A similar decrease was also noted after 14 days (1.46 log CFU/g). Psychrotrophic bacteria can grow at temperatures below $7{ }^{\circ} \mathrm{C}$. Caldara et al. observed that these microorganisms grew faster in meat during the season when the atmospheric temperature was high [16]. Compared with the controls, the NYM at $0.1 \%$ cellulase concentration reflected a reduction of approximately $1.11 \log$ cycles and $0.76 \log$ cycles after 7 and 14 days of storage, respectively. Some yeasts tolerate acidic $\mathrm{pH}$ below 5.5 and are able to grow at temperatures above $0{ }^{\circ} \mathrm{C}$. Molds are also able to grow at temperatures slightly above freezing [17]. On the other hand, Caldara et al., who investigated normal meat and PSE meat for yeast and mold growth, found no significant differences during the storage period [16]. The authors reported that the number of these 
microorganisms increased by $4.73 \log$ cycles in the normal meat and by 5.26 log cycles in the PSE meat after 10 days of storage, with the numbers falling after this time.

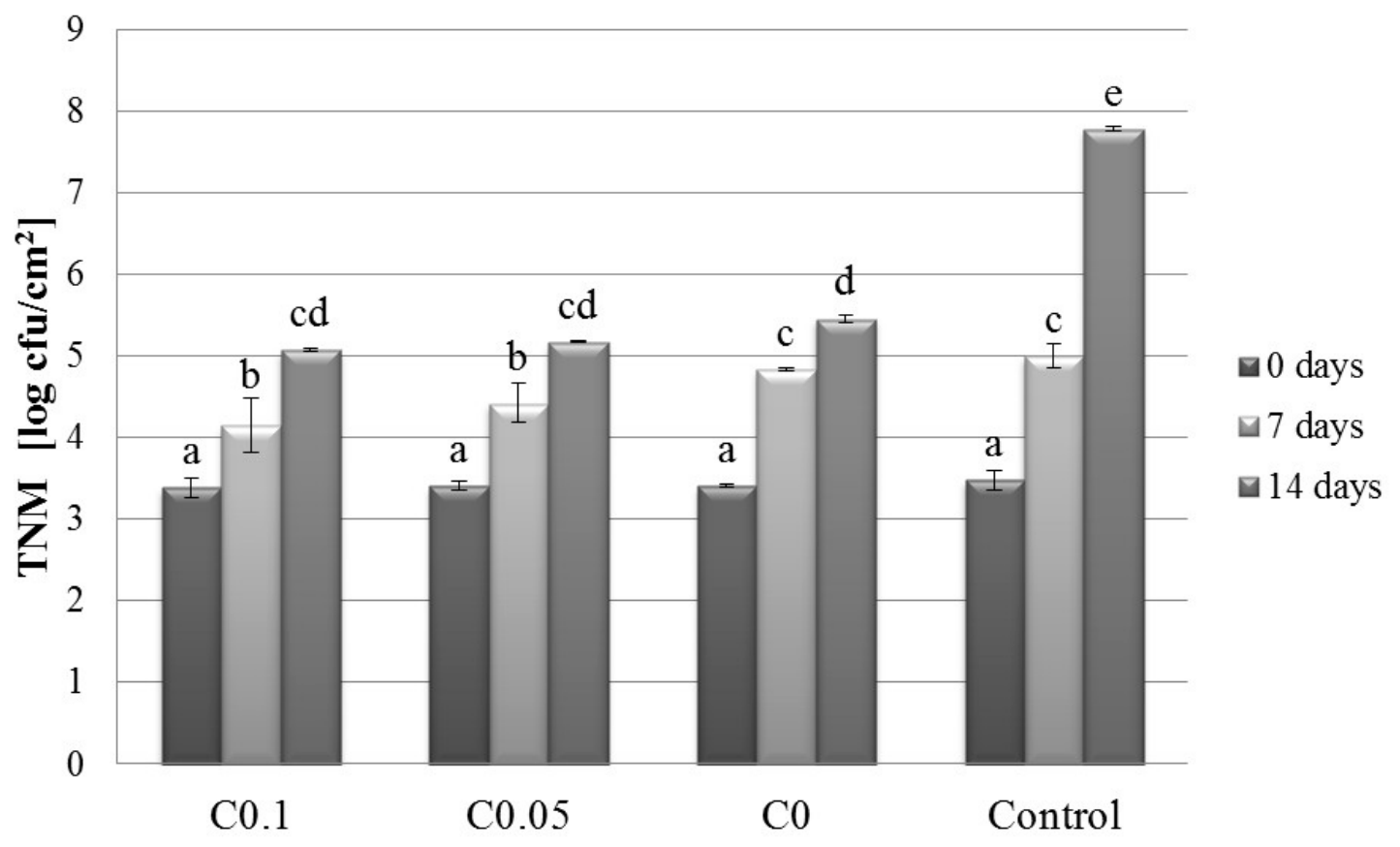

Figure 1. Effect of cellulase concentration and storage time on the total number of microorganisms in pork meat. Results are expressed as the mean \pm standard error. Values with different letters (a-e) within the same column differ significantly $(p<0.05)$. Control-uncoated meat; C0-0\% cellulase; C0.05-0.05\% cellulase; C0.1-0.1\% cellulase.

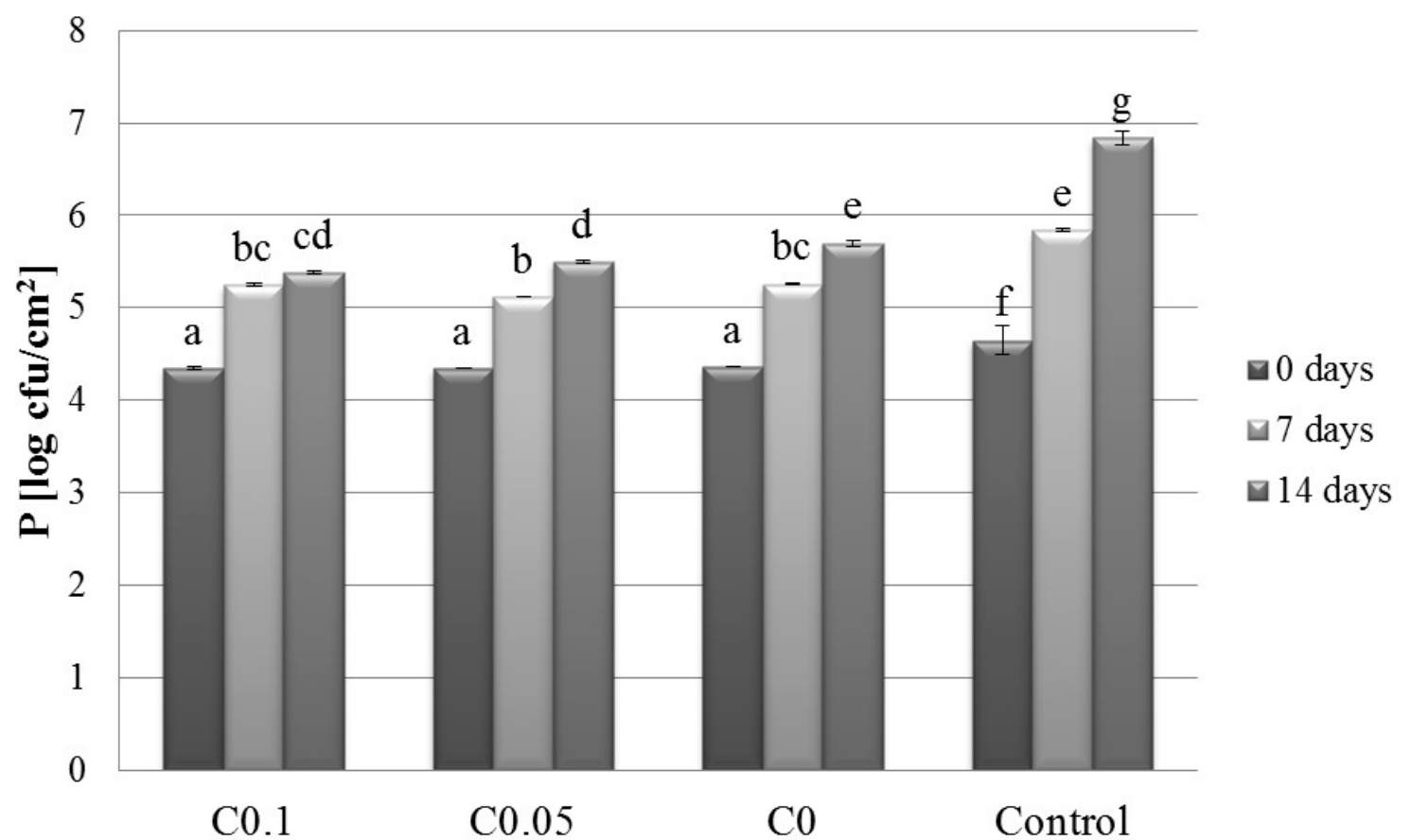

Figure 2. Effect of cellulase concentration and storage time on psychrotrophs population of meat pork. Results are expressed as the mean \pm standard error. Values with different letters $(\mathrm{a}-\mathrm{g})$ within the same column differ significantly $(p<0.05)$. Control-uncoated meat; C $0-0 \%$ cellulase; $0.05-0.05 \%$ cellulase; C0.1-0.1\% cellulase. 


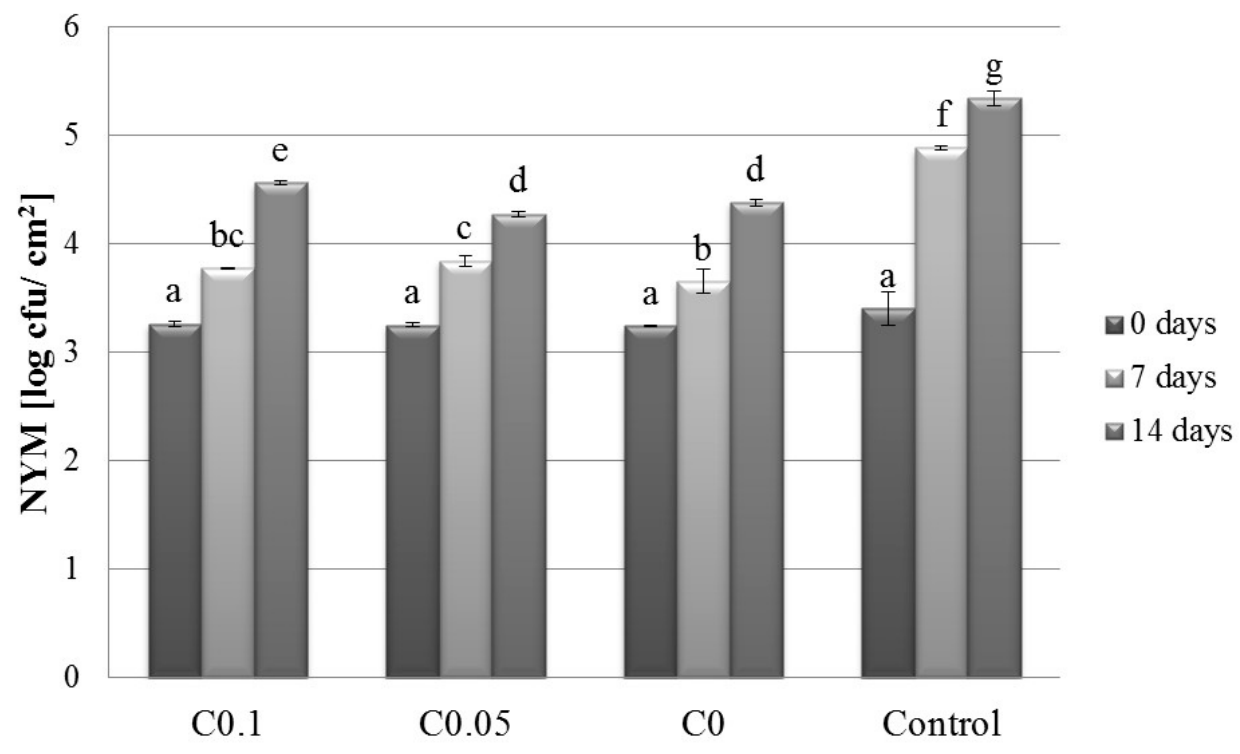

Figure 3. Effect of cellulase concentration and storage time on the number of yeast and mold in pork meat. Results are expressed as the mean \pm standard error. Values with different letters $(\mathrm{a}-\mathrm{g})$ within the same column differ significantly $(p<0.05)$. Control-uncoated meat; C0-0\% cellulase; C0.05-0.05\% cellulase; C0.1-0.1\% cellulase.

The inhibitory effect of added cellulase is because of its ability to hydrolyse chitosan. Chantarasapatorn et al. found that oligochitosans act as effective food preservatives in a minced pork model [18]. These authors noted that the water soluble oligochitosans significantly improved antimicrobial activity and extended the shelf-life while maintaining the meat quality. Additionally, chitosan can be dissolved in simple acid solution, and it appears that the presence of lactic acid in the coating material can potentially have a beneficial effect. The simultaneous effect of all of these factors may have contributed to the microbial growth reduction. This fits the definition of the hurdles technology, which is commonly used for preserving food products. This technology exploits the synergistic action of many factors, resulting in robust microbial growth inhibition, whereas each factor acting alone would be less effective [19]. The sensory changes are noticeable at $10^{6}$ to $10^{9} \mathrm{CFU}$ of spoilage microorganisms/g of meat [20]. On the other hand, the bacterial counts are still at an acceptable level when their amount is less than $10^{6} \mathrm{CFU} / \mathrm{g}$ [12]. Based on these limits, it is clear that the shelf-life of fresh pork meat was extended and the chitooligomers effectively inhibited the microbial growth.

\subsection{Physico-Chemical Parameters}

The results on the interaction effects of the physico-chemical parameters $\left(\mathrm{pH}, \mathrm{a}_{\mathrm{w}}, \mathrm{L}^{*}, \mathrm{a}^{*}, \mathrm{~b}^{*}\right.$, TBARS) are presented in Table 1 . Cellulase addition and storage time significantly affected the $\mathrm{pH}$ value. Fourteen days of storage at $0.1 \%$ cellulase resulted in increased $\mathrm{pH}$ compared with the sample C0T0. Zhao et al. have reported that the $\mathrm{pH}$ of the vacuum-packed pork during cold storage increased from 5.72 to 5.99 after 0 and 21 days, respectively [12]. The initial $\mathrm{pH}$ of the Control (meat) T0 was 5.52, and this value remained nearly unchanged during the storage. It appeared that the $\mathrm{pH}$ was stabilized by other components of the coating material, such as chitosan or lactic acid. During the storage, the $\mathrm{pH}$ changed to a higher value due to the buffering capacity of meat. The $\mathrm{pH}$ is an important factor in meat quality assessment. The normal muscle $\mathrm{pH}$ is in the range of 5.5-5.7. The acidic environment of the meat does not support the growth of microorganisms except lactic acid bacteria, which are able to grow under such conditions and cause spoilage. The genera Lactobacillus, Leuconostoc, and Carnobacterium are dominant under these conditions [17]. The lack of air at this range of $\mathrm{pH}$ restricts the growth of Pseudomonas, Enetrobacteriacea, Brochothrix tchermosphacta, Aeromonas, and Alteromonas putrefaciens at 
$0-5{ }^{\circ} \mathrm{C}$ [21]. On the other hand, Garcia-Lopez et al. reported the growth of Shewanella putrefaciens, Alcaligenes spp., Aeromonas spp., and other species of Enterobacteriaceae at pH below 6 [22].

Table 1. Effect of cellulase addition and storage time on the physico-chemical parameters of coated meat.

\begin{tabular}{|c|c|c|c|c|c|c|}
\hline \multirow{2}{*}{$\begin{array}{l}\text { Interaction Effects } \\
\mathrm{C} \times \mathrm{T}^{*}(\% \times \text { Days })\end{array}$} & \multicolumn{6}{|c|}{ Parameters } \\
\hline & $\mathrm{pH}$ & $\mathbf{a}_{\mathbf{w}}$ & $\mathbf{L}^{*}$ & $a^{*}$ & $\mathbf{b}^{*}$ & $\begin{array}{c}\text { TBARS }^{\#} \\
\text { (mg MDA/kg) }\end{array}$ \\
\hline сот0 & $5.47 \pm 0.01 \mathrm{ab}$ & $0.925 \pm 0.001^{b}$ & $53.91 \pm 0.34^{\text {ac }}$ & $6.89 \pm 0.62 \mathrm{abc}$ & $4.82 \pm 0.20^{\mathrm{ab}}$ & $0.26 \pm 0.05^{\mathrm{a}}$ \\
\hline С0.05T0 & $5.42 \pm 0.02^{\mathrm{e}}$ & $0.926 \pm 0.001^{b}$ & $52.78 \pm 0.40^{a}$ & $5.76 \pm 0.65^{\mathrm{ab}}$ & $3.71 \pm 0.55^{\text {af }}$ & $0.25 \pm 0.01^{\mathrm{a}}$ \\
\hline C0.1T0 & $5.43 \pm 0.01^{\mathrm{e}}$ & $0.925 \pm 0.001^{b}$ & $51.89 \pm 1.82^{\mathrm{a}}$ & $6.20 \pm 0.09^{a b}$ & $2.77 \pm 1.01^{\mathrm{f}}$ & $0.26 \pm 0.01^{\mathrm{a}}$ \\
\hline C0T7 & $5.48 \pm 0.01^{\mathrm{d}}$ & $0.921 \pm 0.001^{\mathrm{a}}$ & $59.45 \pm 0.30^{\mathrm{bd}}$ & $5.47 \pm 0.33^{\mathrm{a}}$ & $8.23 \pm 0.40$ de & $0.68 \pm 0.02^{d}$ \\
\hline C0.05T7 & $5.51 \pm 0.01^{\mathrm{ac}}$ & $0.921 \pm 0.000^{\mathrm{a}}$ & $55.13 \pm 1.43^{\mathrm{ac}}$ & $6.22 \pm 0.21^{\mathrm{ab}}$ & $4.86 \pm 0.80^{a b}$ & $0.66 \pm 0.01^{c}$ \\
\hline C0.1T7 & $5.54 \pm 0.01^{b}$ & $0.919 \pm 0.000^{d}$ & $52.61 \pm 0.56^{\mathrm{a}}$ & $8.28 \pm 0.54^{c}$ & $7.13 \pm 0.29$ cde & $0.53 \pm 0.01^{b}$ \\
\hline C0T14 & $5.47 \pm 0.01^{\mathrm{ac}}$ & $0.923 \pm 0.000^{c}$ & $60.61 \pm 1.04^{\mathrm{d}}$ & $7.37 \pm 0.30^{b c}$ & $8.85 \pm 0.17^{\mathrm{e}}$ & $1.28 \pm 0.01^{h}$ \\
\hline C0.05T14 & $5.50 \pm 0.02^{c}$ & $0.922 \pm 0.000^{\mathrm{a}}$ & $56.90 \pm 0.76^{\mathrm{bc}}$ & $6.85 \pm 0.62^{a b}$ & $5.95 \pm 0.92^{b c}$ & $1.08 \pm 0.21 \mathrm{~g}$ \\
\hline C0.1T14 & $5.52 \pm 0.01 \mathrm{abc}$ & $0.921 \pm 0.001^{\mathrm{a}}$ & $59.63 \pm 2.02^{b d}$ & $6.30 \pm 0.49^{a b}$ & $6.83 \pm 0.63^{\mathrm{cd}}$ & $1.05 \pm 0.02^{f}$ \\
\hline Control (meat) T0 & $5.52 \pm 0.00^{\mathrm{ab}}$ & $0.926 \pm 0.000^{b}$ & $58.62 \pm 0.06^{b d}$ & $8.57 \pm 1.21^{c}$ & $0.95 \pm 0.32 \mathrm{~g}$ & $0.26 \pm 0.01^{\mathrm{a}}$ \\
\hline Control (meat) T7 & $5.52 \pm 0.01 \mathrm{abc}$ & $0.922 \pm 0.001 \mathrm{ac}$ & $56.31 \pm 0.77^{b c}$ & $5.69 \pm 0.11^{\mathrm{ab}}$ & $5.02 \pm 0.24^{\mathrm{ab}}$ & $0.97 \pm 0.01^{\mathrm{e}}$ \\
\hline Control (meat) T14 & $5.54 \pm 0.00^{\mathrm{b}}$ & $0.921 \pm 0.000^{\mathrm{a}}$ & $38.01 \pm 1.14^{\mathrm{e}}$ & $3.68 \pm 0.20^{\mathrm{d}}$ & $7.46 \pm 0.27^{\text {cde }}$ & $1.54 \pm 0.01^{\mathrm{i}}$ \\
\hline
\end{tabular}

The $a_{w}$ values are presented in Table 1 . The water activity of the coated pork was mainly affected by storage time and slightly affected by the enzyme addition. The range of $\mathrm{a}_{\mathrm{w}}$ in the interactions was 0.921-0.926. The growth of microorganisms is possible only in the presence of water. Most pathogenic bacteria grow faster when the water activity is between $0.90-0.99$ [23]. The water activity of normal fresh pork meat is in the range of 0.98-0.99. Leistner reported that meat and meat products easily perish at $\mathrm{a}_{\mathrm{w}}>0.95$ and $\mathrm{pH}>5.2$ [24]. In comparison with bacteria and yeast, which grow at an $\mathrm{a}_{\mathrm{w}}$ of 0.88 , fungi can grow at lower $\mathrm{a}_{\mathrm{w}}$ values of 0.80 and 0.91 .

Results from the analysis of interactions confirmed the simultaneous effect of cellulase and storage time on $\mathrm{L}^{*}, \mathrm{a}^{*}$, and $\mathrm{b}^{*}$. Samples became lighter with the prolonged storage time and darker with the rising concentration of cellulase. The colour changes were likely related to the reduction in oxygen tension, caused by vacuum-packing. Grajales-Lagunes et al. have reported that lactic acid does not contribute to the colour changes in pork [25]. The lightness of the initial meat sample was 58.62 and after 14 days of storage was 38.01. The C0T0 sample showed an L value of 53.91 and reached 59.63 in the final sample R10T14. This could be related to the creation of a transparent and bright film by HPMC and $\mathrm{CH}$. In general, higher $\mathrm{L}^{*}$ values are desirable. The decreased lightness value of the meat during storage is generally associated with an unattractive brown colour. This colour is due to the oxidation of red oxymyoglobin to metmyoglobin [26]. We also observed a reduction in the redness from 8.57 of the Control (meat) T0 to 6.89 of C0T0 and 6.30 of C0.1T14. However, the Control (meat) T0, C0T0, C0T0, and C0.1T14 were still in the common homogenous group, confirming the stability of redness. The $\mathrm{a}^{*}$ value of the meat sample coated with material containing cellulase was significantly higher compared to the Control (meat) T7 and Control (meat) T14. Jo et al. (2001) reported that chitosan oligomer addition increased the Hunter colour $\mathrm{a}^{*}$-value of pork sausage after 1 and 2 weeks of storage with aerobic packaging [27]. The antioxidant potential of chitosan could improve the redness stability of pork slices. Zahran reported that when compared with meat dipped in water and stored for the same duration, chitosan oligomers produced by $100 \mathrm{kGy}$ irradiation caused significant improvement in the $\mathrm{a}^{*}$-value of meat slices during 14 days of storage [28]. Mokhtar et al. reported that both chitosan and chitosan in combination with rosemary extract improved the red colour of fresh beef patties [29]. Beef samples became more yellow with storage and cellulase addition. The colour of meat and meat products is an important factor influencing the consumer's purchase decision. Therefore, the deterioration of the colour of meat and meat products is a serious problem in the meat industry. 
The effect of both factors on TBARS values is clearly observed. Cellulase addition and storage time significantly lowered the TBARS values. The initial TBARS values of the meat was $0.26 \mathrm{mg}$ $\mathrm{MDA} / \mathrm{kg}$, which increased to 0.97 and $1.54 \mathrm{mg} \mathrm{MDA} / \mathrm{kg}$ after 7 and 14 days of storage, respectively. The TBARS of all coated samples at time 0 was approximately $0.25-0.26 \mathrm{mg}$ MDA $/ \mathrm{kg}$. After 7 days of storage, these values significantly increased to $0.53-0.68 \mathrm{mg} \mathrm{MDA} / \mathrm{kg}$, reaching $1.05-1.28 \mathrm{mg} \mathrm{MDA} / \mathrm{kg}$ after 14 days of storage. An increase in the concentration of cellulase resulted in significantly reduced TBARS values after 7 and 14 days of storage. This reduction in TBARS was also observed in the case of meat coated without cellulase, but the magnitude of the change was smaller. Zahran reported that there was no significant differences between the MDA values of beef slices dipped in chitosan and chitosan oligomers [28]. Although Chantarasataporn et al. found a significant reduction in TBARS of minced meat treated with oligochitosans, their concentration had no effect on the TBARS value [18]. Free radicals that occur in lipid oxidation are secondary products and may be investigated by the TBARS method. The amino group of deacetylated chitosan may interact with free radicals and form stable macromolecules, inhibiting lipid oxidation [30].

\section{Materials and Methods}

\subsection{Materials}

Low-molecular-weight chitosan (DD = 75\%-85\%), DL-lactic acid ( $85 \%$ syrup) and $99 \%$ glycerol were obtained from Sigma Aldrich, Poznań, Poland. Hydroxypropyl methylcellulose, Methocel ${ }^{\mathrm{TM}}$, was purchased from Dow Chemical Co., Midland, MI, USA. Cellulase CP CONC (C) with an activity of $120 \mathrm{U} / \mathrm{mg}$ and side activity (typical) of $30 \mathrm{U} / \mathrm{mg}$ of $\beta$-glucanase was produced by the fermentation of non-GMO Trichoderma longibrachiatum (formerly Trichoderma reesei) that was obtained from Dyadic (Jupiter, FL, USA).

\subsection{Coat-Forming Solution}

The $2 \%$ HPMC stock solution was dissolved in distilled water and the $\mathrm{CH}$ stock solution was solubilized in $1 \%(v / v)$ aqueous lactic acid (LA) to the concentration of $4 \%$. Cellulase stock solution (C) was prepared by dissolving the material in distilled water, followed by centrifugation (5000 $\mathrm{g}$ ). Glycerol (G) was added such that its amount was $25 \% w / w$ of the dry weight of the polymers used. The HPMC (50 mL) and CH ( $25 \mathrm{~mL})$ stock solutions were blended with $\mathrm{G}$ and $\mathrm{C}$ (at three different concentrations: $0 \%, 0.05 \%$ and $0.1 \% ; w / w)$ and distilled water was added to increase the volume to $100 \mathrm{~mL}$. The final concentrations of $\mathrm{CH}, \mathrm{HPMC}$, and LA in the coatings were $1 \%, 1 \%$, and $0.25 \%$, respectively (Table 2). The $\mathrm{pH}$ values of the coat-forming solutions $\mathrm{C} 0 \mathrm{T0}-\mathrm{C} 0.1 \mathrm{~T} 14$ were determined using a pH-meter (Handylab Schott Instruments, Mainz, Germany) and was $5.45 \pm 0.08$.

Table 2. Experimental design.

\begin{tabular}{cccccccc}
\hline & \multicolumn{2}{c}{ Variables } & \multicolumn{5}{c}{ Constant Factors } \\
\cline { 2 - 7 } Variants Coding * & $\begin{array}{c}\text { Cellulase } \\
\mathbf{( \% )}\end{array}$ & $\begin{array}{c}\text { Time } \\
\text { (Days) }\end{array}$ & $\begin{array}{c}\text { Chitosan } \\
(\mathbf{\%})\end{array}$ & $\begin{array}{c}\text { HPMC } \\
\mathbf{( \% )}\end{array}$ & $\begin{array}{c}\text { Glycerol } \\
\mathbf{( \% )}\end{array}$ & $\begin{array}{c}\text { Lactic } \\
\text { Acid (\%) }\end{array}$ & Sample \\
\hline C0T0 & 0 & 0 & 1 & 1 & 25 & 0.25 & Meat slice \\
C0.05T0 & 0.05 & 0 & 1 & 1 & 25 & 0.25 & Meat slice \\
C0.1T0 & 0.1 & 0 & 1 & 1 & 25 & 0.25 & Meat slice \\
C0T7 & 0 & 7 & 1 & 1 & 25 & 0.25 & Meat slice \\
C0.05T7 & 0.05 & 7 & 1 & 1 & 25 & 0.25 & Meat slice \\
C0.1T7 & 0.1 & 7 & 1 & 1 & 25 & 0.25 & Meat slice \\
C0T14 & 0 & 14 & 1 & 1 & 25 & 0.25 & Meat slice \\
C0.05T14 & 0.05 & 14 & 1 & 1 & 25 & 0.25 & Meat slice \\
C0.1T14 & 0.1 & 14 & 1 & 1 & 25 & 0.25 & Meat slice \\
Control (meat) T0 & - & 0 & - & - & - & - & Meat slice \\
Control (meat) T7 & - & 7 & - & - & - & - & Meat slice \\
Control (meat) T14 & - & 14 & - & - & - & - & Meat slice \\
\hline
\end{tabular}

- Not applied. ${ }^{*} \mathrm{C}=$ cellulase, $\mathrm{T}=$ storage time of sample. 


\subsection{Meat Sampling}

Three pig longissimus thoracis (LT) muscle samples were obtained within $48 \mathrm{~h}$ of slaughtering from a commercial slaughterhouse and sliced into twelve $20 \pm 0.3-\mathrm{mm}$ thick portions. The meat slices were sprayed with the desired coat-forming solutions, vacuum packed in PA/PE (polyamide/polyethylene) foil pouches, and stored at $4{ }^{\circ} \mathrm{C}$ in a cold room. The samples were analysed after 0,7 , and 14 days (Table 2) for $\mathrm{pH}, \mathrm{a}_{\mathrm{w}}, \mathrm{TNM}, \mathrm{P}, \mathrm{NYM}$, colour, and TBARS. Each sample was tested for all parameters. The $\mathrm{pH}$ values were determined using a $\mathrm{pH}$-meter (Handylab Schott Instruments) equipped with a flat-tip pH electrode for surfaces (Hanna Instruments, Woonsocket, RI, USA). The water activity was determined using an AW LAB Set $\mathrm{H} \mathrm{a}_{\mathrm{w}}$-meter (Novasina AG). Samples of meat slices, cylindrical in shape with a diameter of $38 \mathrm{~mm}$ and a height of $10 \mathrm{~mm}$, were cut and transferred into the disposable cup of the water activity meter such that the vapour from the coated meat was in equilibrium with the surrounding air.

\subsection{Microbial Sampling}

Sterile cotton swabs were used for sampling the product surface in accordance with ISO 18593:2004 [31]. The swab head was moistened with sterile saline solution, and excess saline was removed by pressing the swab head against the interior wall of a vial with a rotating motion. A sampling template with a $5 \mathrm{~cm} \times 5 \mathrm{~cm}$ opening was used to define the sample size and to determine the number of colony forming units (CFU) per $\mathrm{cm}^{2}$. After the area was swabbed, the swab head was placed in a vial and a series of dilutions of the sample was made [32]. Only plates (or replicate plates from the same dilution) with 30-300 colonies were counted.

\subsubsection{Total Number of Microorganisms of Meat Sample Covered by Hydrosol}

The TNM values were determined by examining the colonies formed on agar after incubating the plates at $30{ }^{\circ} \mathrm{C}$ for $72 \mathrm{~h}$ according to ISO 2293:1988 [33]. The culture medium used in the agar (Merck, Darmstadt, Germany) plate was prepared according to standard procedures using tryptone (BTL Ltd., Lodz, Poland), yeast extract (Merck), and glucose broth (BTL Ltd.). The samples were plated in duplicate and the results were averaged. Colonies grown on the plate were counted automatically after the incubation. The results were expressed as $\log \mathrm{cfu} / \mathrm{cm}^{2}$.

\subsubsection{Psychrotrophs}

Psychrotrophs were determined on PCA plates (hydrolysed casein (BTL Ltd.), yeast extract, glucose, agar) incubated at $6{ }^{\circ} \mathrm{C}$ for 10 days [34]. The samples were plated in duplicate and the results were averaged. The grown colonies were counted automatically at the end of the incubation period. The results were expressed as $\log \mathrm{cfu} / \mathrm{cm}^{2}$.

\subsubsection{Number of Yeast and Mold}

Culture medium supplemented with chloramphenicol (Sigma-Aldrich, Poznan, Poland) was used for the determination of NYM. Other components of the medium were yeast extract, glucose, and agar. The plates were incubated for 5 days at $25^{\circ} \mathrm{C}$ [35] and colonies were counted automatically. Samples were plated in duplicate and the results were averaged and expressed as $\log \mathrm{cfu} / \mathrm{cm}^{2}$.

\subsection{Colour Measurement}

Before and after coating, the meat colour was measured using a Minolta $\mathrm{Cr} 400$ colourimeter. The chroma meter was set at D65 illuminant and $10^{\circ}$ standard observer. The results were expressed in the CIE LAB (Commission Internationale de $1^{\prime}$ Eclairage $L^{*} a^{*} b^{*}$ parameters) colour scale, where $L^{*}$ indicated lightness, $a^{*}$ redness, and $b^{*}$ yellowness. The $L^{*}$ value ranges from $0-100$, where 0 represents black and 100 represents a perfect reflecting diffuser. The $\mathrm{a}^{*}$ and $\mathrm{b}^{*}$ indicate colour directions, where $+a^{*}$ is red; $-a^{*}$ is green; $b^{*}$ is yellow; and $-b^{*}$ is blue. 


\subsection{Thiobarbituric Acid Reactive Substances (TBARS) Measurement}

From each treatment group, $10 \mathrm{~g}$ of ground pork was homogenized with $25 \mathrm{~mL}$ of trichloroacetic acid (TCA) solution for $30 \mathrm{~s}$ and filtered. The TCA solution consisted of $200 \mathrm{~g} / \mathrm{L}$ of TCA dissolved in a $135 \mathrm{~mL} / \mathrm{L}$ solution of phosphoric acid. Five millilitres of the filtrate was mixed with $2 \mathrm{~mL}$ of $20 \mathrm{mM}$ thiobarbituric acid, heated in boiling water for $20 \mathrm{~min}$, cooled in cold water for $10 \mathrm{~min}$, and centrifuged for $15 \mathrm{~min}$ at $5500 \mathrm{~g}$. The absorbance at $532 \mathrm{~nm}$ was measured using a UV 1800 model spectrophotometer (Rayleigh Instruments Limited, Sevenoaks, UK). The level of TBARS was quantified from the absorbance of the samples with the help of an equation and a standard curve constructed using malondialdehyde (MDA) as a standard. The TBARS values were expressed as mg MDA per kg meat.

\subsection{Statistical Analysis}

This study analysed nine different muscles, 12 experimental meat coating conditions, and the meat slices themselves as controls $(n=108)$ for three analytical repetitions. The experimental design was a randomized design and measurements were made in triplicate. From each muscle, 12 slices of each variant were obtained. The effect of cellulase concentration $(0 \%, 0.05 \%, 0.1 \%)$ and storage time $(0,7,14$ days) on the TNM, P, NYM, colour changes, and lipid oxidation changes of the meat were examined using a two way ANOVA (Statistic 9, StatSoft Poland, Cracow, Poland), where the measured variables were set as dependent variables, cellulase concentration and storage time as fixed effects, and replicates as random effects. The mean values and the standard errors of the mean were reported. The differences between means were established by the Duncan Test with a confidence level set at $p<0.05$.

\section{Conclusions}

Cellulase was added to the edible coating material consisting of HPMC and $\mathrm{CH}$ to improve the quality of stored pork and extend its shelf-life. Cellulase improved the antimicrobial activity of chitosan on the surface of meat. The addition of cellulase led to a significant reduction in the total number of microorganisms and psychotropic bacteria, as well as yeast and mold. The coatings stabilized the $\mathrm{a}_{\mathrm{w}}$ and $\mathrm{pH}$ of the pork meat in cold storage for 14 days. The reduction in TBARS values as well as the slight changes in the $\mathrm{a}^{*}$ parameter confirmed the positive effect of cellulase in the coating formation, leading to the production of bioactive polysaccharides oligomers. Meat coated with a mixture of HPMC, $\mathrm{CH}$, and $0.05 \%$ cellulase can be stored in cold conditions for 7 days. Doubling the enzyme concentration extends this time to 14 days or longer. Thus, such coatings guarantee meat safety and extend the shelf-life of pork meat.

Acknowledgments: Publication supported by Wroclaw Centre of Biotechnology, programme The Leading National Research Centre (KNOW) for years 2014-2018.

Author Contributions: A.Z.-K. and A.J. conceived and designed the experiments; A.Z.-K. performed the experiments; A.Z.-K. and A.J. analyzed the data; A.Z.-K. contributed reagents/materials/analysis tools; A.Z.-K. wrote the paper.

Conflicts of Interest: The authors declare no conflict of interest. The founding sponsors had no role in the design of the study; in the collection, analyses, or interpretation of data; in the writing of the manuscript, and in the decision to publish the results.

\section{References}

1. Khan, M.I.; Adrees, M.N.; Tariq, M.R.; Sohaib, M. Application of edible coating for improving meat quality: A review. Pakistan J. Food Sci. 2013, 23, 71-79.

2. Huang, G.Q.; Sun, Y.T.; Xiao, J.X.; Yang, J. Complex coacervation of soybean protein isolate and chitosan. Food Chem. 2012, 135, 534-539. [CrossRef] [PubMed]

3. Xia, X.-F.; Kong, B.-H. Extending shelf life of chilled pork by combination of chitosan coatings with spice extracts. J. Northeast. Agric. Univ. 2008, 15, 33-37. 
4. Kanatt, S.R.; Rao, M.S.; Chawla, S.P.; Sharma, A. Effects of chitosan on shelf life of ready to cook meat products during chilled stored. LWT-Food Sci. Technol. 2013, 53, 321-326. [CrossRef]

5. Zimoch-Korzycka, A.; Jarmoluk, A. The use of chitosan, lysozyme, and the nano-silver as antimicrobial ingredients of edible protective hydrosols applied into the surface of meat. J. Food Sci. Technol. 2015, 52, 5996-6002. [CrossRef] [PubMed]

6. Xie, H.; Jia, Z.; Huang, J.; Zhang, C. Preparation of Low Molecular Weight Chitosan by Complex Enzymes Hydrolysis. Int. J. Chem. 2011, 3, 180-186. [CrossRef]

7. Benhabiles, M.S.; Salah, R.; Lounici, H.; Drouiche, N.; Goosen, M.F.A.; Mameri, N. Antibacterial activity of chitin, chitosan and its oligomers prepared from shrimp shell waste. Food Hydrocoll. 2012, 29, 48-56. [CrossRef]

8. Fernandes, J.C.; Tavaria, F.K.; Soares, J.C.; Ramos, O.S.; Monteiro, M.J.; Pintado, M.E.; Xavier Malcata, F. Antimicrobial effects of chitosans and chitooligosaccharides, upon Staphylococcus aureus and Escherichia coli, in food model systems. Food Microbiol. 2008, 25, 922-928. [CrossRef] [PubMed]

9. Rabea, E.I.; Badawy, M.E.T.; Stevens, C.V.; Smagghe, G.; Steurnaut, W. Chitosan as antimicrobial agent: Applications and mode of action. Biomacromolecules 2003, 4, 1457-1465. [CrossRef] [PubMed]

10. Zimoch-Korzycka, A.; Ambrozik-Haba, J.; Kulig, D.; Jarmoluk, A. Modification Effect of Cellulase on the Physicochemical Characteristic of Polysaccharides Edible Films. Int. J. Polym. Sci. 2015, 184616. [CrossRef]

11. Malinowska-Pańczyk, E.; Kołodziejska, I. The influence of moderate pressure and subzero temperature on the shelf life of minced cod, salmon, pork and beef meat. Food Technol. Biotechnol. 2013, 51, 570-576.

12. Zhao, F.; Zhou, G.; Ye, K.; Wang, S.; Xu, X.; Li, C. Microbial changes in vacuum-packed chilled pork during storage. Meat Sci. 2015, 100, 145-149. [CrossRef] [PubMed]

13. Sagoo, S.; Board, R.; Roller, S. Chitosan inhibits growth of spoilage microorganisms in chilled pork products. Food Microbiol. 2002, 19, 175-182. [CrossRef]

14. Tsai, G.J.; Su, W.H.; Chen, H.C.; Pan, C.L. Antimicrobial activity of shrimp chitin and chitosan from different treatments and applications of fish preservation. Fish. Sci. 2002, 68, 170-177. [CrossRef]

15. Zimoch-Korzycka, A.; Gardrat, C.; Castellan, A.; Coma, V.; Jarmoluk, A. The use of lysozyme to prepare biologically active chitooligomers. Polimeros 2015, 25, 35-41. [CrossRef]

16. Caldara, F.R.; Santos, L.S.; Nieto, V.M.O.; Foppa, L.; Santos, R.K.S.; Paz, I.C.L.A.; Garcia, R.G.; Nääs, I.A. Microbiological growth in normal and PSE pork stored under refrigeration. Rev. Bras. Saúde Prod. Anim. 2014, 15, 459-469. [CrossRef]

17. Sun, X.D.; Holley, R.A. Antimicrobial and antioxidative strategies to reduce pathogens and extend the shelf life of fresh red meats. Comp. Rev. Food Sci. Food Saf. 2012, 11, 340-354. [CrossRef]

18. Chantarasataporn, P.; Tepkasikul, P.; Kingcha, Y.; Yoksan, R.; Pichyangkura, R.; Visessanguan, W.; Chirachanchai, S. Water-based oligochitosan and nanowhisker chitosan as potential food preservatives for shelf-life extension of minced pork. Food Chem. 2014, 159, 463-470. [CrossRef] [PubMed]

19. Leistner, L.; Gould, G.W. Hurdle Technologies: Combination Treatment for Food Stability, Safety and Quality; Kluwer Academic/Plenum Publishers: New York, NY, USA, 2002.

20. Gill, A.O.; Gill, C.O. Preservative packaging for fresh meats, poultry, and fin fish. In Innovations in Food Packaging; Han, J.H., Ed.; Elsevier Academic: New York, NY, USA, 2005; pp. 204-226.

21. Egan, A.F.; Eustace, I.J.; Shay, B.J. Meat packaging-Maintaining the quality and prolonging the storage life of chilled beef, pork and lamb. In Proceedings of the 34th International Congress of Meat Science and Technology, Brisbane, Australia, 1998; Volume 34, pp. 68-75.

22. Garcia-Lopez, M.L.; Prieto, M.; Otero, A. The physiological attributes of Gram-negative bacteria associated with spoilage of meat and meat products. In The microbiology of Meat and Poultry; Davies, A., Board, R., Eds.; Blackie Academic and Professional: London, UK, 1998; pp. 1-34.

23. Araújo, L.F.; Oliveira, L.S.C.; Perazzo Neto, A.; Alsina, O.L.S.; Silva, F.L.H. Equilíbriohigroscópico da palma forrageira: Relação com a umidade ótima parafermentação sólida. Rev. Bras. Eng. Agríc. Ambient 2005, 9, 379-384. [CrossRef]

24. Leistner, L. Microbiology of ready-to-serve foods. Die Fleischwirtsch. 1978, 58, 2008-2011.

25. Grajales-Lagunes, A.; Rivera-Bautista, C.; Ruiz-Cabrera, M.; Gonzalez-Garcia, R.; Ramirez-Telles, J.; Abud-Archila, M. Effect of lactic acid on the meat quality properties and the taste of pork Serratus ventralis muscle. Agric. Food Sci. 2012, 21, 171-181. 
26. Nerín, C.; Tovar, L.; Djenane, D.; Camo, J.; Salafranca, J.; Beltrán, J.A.; Roncalés, P. Stabilization of beef meat by a new active packaging containing natural antioxidants. J. Agric. Food Chem. 2006, 52, 5598-5605.

27. Jo, C.; Lee, J.W.; Lee, K.H.; Byun, M.W. Quality properties of pork sausage prepared with water-soluble chitosan oligomer. Meat Sci. 2001, 59, 369-375. [CrossRef]

28. Zahran, D.A. Effectiveness of Gamma Irradiated Chitosan for Fresh Meat Preservation. Arab J. Nucl. Sci. Appl. 2015, 48, 143-152.

29. Mokhtar, S.M.; Youssef, K.M.; Morsy, N.E. The effects of natural antioxidants on colour, lipid stability and sensory evaluation of fresh beef patties stored at $4{ }^{\circ} \mathrm{C}$. J. Agroaliment. Process. Technol. 2014, 20, $282-292$.

30. Park, P.J.; Je, J.Y.; Kim, S.K. Free radical scavenging activities of differently deacetylated chitosans using an ESR spectrometer. Carbohydr. Polym. 2004, 55, 17-22. [CrossRef]

31. ISO 18593:2004. Microbiology of Food and Animal Feeding Stuffs; Horizontal Methods for Sampling Techniques from Surfaces Using Contact Plates and Swabs; ISO: London, UK, 2004.

32. ISO 17604:2003. Microbiology of Food and Animal Feeding Stuffs; Carcass Sampling for Microbiological Analysis; ISO: London, UK, 2003.

33. ISO 2293:1988. Meat and Meat Products. Enumeration of Microorganisms; Colony Count Technique at $30^{\circ} \mathrm{C}$; ISO: London, UK, 1988.

34. ISO 17410:2001. Microbiology of Food and Animal Feeding Stuffs; Horizontal Method for the Enumeration of Psychrotrophic Microorganisms; ISO: London, UK, 2001.

35. ISO 215271:2008. Microbiology of Food and Animal Feeding Stuffs; Horizontal Method for the Enumeration of Yeasts and Molds. Part 1: Colony count Technique in Products with Water Activity Greater than 0.95; ISO: London, UK, 2008.

Sample Availability: Not available.

(C) 2017 by the authors. Licensee MDPI, Basel, Switzerland. This article is an open access article distributed under the terms and conditions of the Creative Commons Attribution (CC BY) license (http:/ / creativecommons.org/licenses/by/4.0/). 